\title{
PERBEDAAN PERSEPSI MAHASISWA TENTANG PERKULIAHAN DARING
}

\section{The Difference Of Student Perceptions On College Online}

\author{
Rita Rahmaniati ${ }^{*}$ \\ Bulkani2* \\ Email: \\ rahmaniatirita@gmail.com! \\ bulkaniardiansyah@gmail.com² \\ *1,2Universitas Palangka Raya \\ ,Indonesia
}

\author{
Kata Kunci: \\ Persepsi Mahasiswa, Perkuliahan \\ Daring
}

\section{Keywords:}

Student Perceptions, Online Lectures

Accepted

September 2020

Published

December 2020

\begin{abstract}
Abstrak
Penelitian ini bertujuan untuk mengetahui ada tidaknya perbedaan persepsi mahasiswa tentang pembelajaran daring di tinjau dari (I) asal Program Studi mahasiswa, (2) mata kuliah yang ditempuh, dan (3) jenis kelamin.

Populasi dalam penelitian ini adalah mahasiswa FKIP UM Palangkaraya semester Genap tahun akademik 2019/2020. Sampel dalam penelitian ini adalah mahasiswa yang memprogramkan mata kuliah Metodologi Penelitian, Teknik Penulisan Karya Ilmiah, Problematika Pembelajaran, dan mata kuliah Belajar Pembelajaran. Pendekatan penelitian menggunakan pendekatan kuantitatif. Metode pengumpulan data menggunakan angket daring sebanyak 17 butir pertanyaan yang sudah divalidasi. Teknik analisis data menggunakan analisis varian satu jalur dengan bantuan program SPSS.

Hasil penelitian menunjukan bahwa pada populasi mahasiswa FKIP UM Palangkaraya: (I), Tidak ada perbedaan persepsi tentang perkuliahan sistem daring jika ditinjau dari program studi mahasiswa, dengan nilai $F$ hitung $=2,42 \mathrm{I}$ dan Sig $0.122>0.05$, (2) Tidak ada perbedaan persepsi tentang perkuliahan sistem daring jika ditinjau dari jenis mata kuliah yang ditempuh mahasiswa, dengan nilai $\mathrm{F}$ hitung $=1,042$ dan Sig $0.376>0.05$, (3) Ada perbedaan persepsi tentang perkuliahan sistem daring jika ditinjau dari jenis kelamin mahasiswa, dengan nilai $F$ hitung $=15,162$ dan Sig $0.000<0.05$. Dari analisis deskriptif diketahui bahwa mahasiswa laki-laki cenderung memiliki persepsi lebih positif tentang perkuliahan daring dibanding mahasiswa perempuan
\end{abstract}

\begin{abstract}
This study aims to determine whether there are differences in students' perceptions about online learning in terms of (I) Study Programs (2) From Courses (3) of Gender.

The population in this study were UM Palangkaraya students in the even semester of the academic year 2019/2020. The sample in this study were students who programmed Research Methodology, Scientific Writing Techniques, Learning Problems and Learning Learning. The method in this study uses quantitative methods with oneway analysis of variance (ANAVA).
\end{abstract}

The results showed that: $(I)$ there was no difference in perception about online system lectures when viewed from the student study program indicated Sig 0.I22>0.05, (2) there was no difference in perception about online system lectures when viewed from the type of courses taken by students statistic shown Sig 0.376>0.05 (3) there are differences in perceptions about the lectures of the online system when viewed from the sex of students indicated by the statistics Sig $0.000<0.05$.

2020 The Authors. Published by Institute for Research and Community Services Universitas Muhammadiyah Palangkaraya. This is Open Access article under the CC-BYSA License (http://creativecommons.org/licenses/by-sa/4.0/).

\section{PENDAHULUAN}

Keberhasilan pembelajaran ditentukan oleh banyak faktor. Untuk mengukur keberhasilan proses pembelajaran tidak hanya bertumpu pada hasil belajar kognitif saja, tetapi dapat pula diukur melalui tingkat kepuasan peserta didik yang dalam hal ini adalah para mahasiswa. Retno (20I2) menyatakan kepuasan merupakan faktor yang paling penting sebagai tolak ukur dalam menilai kualitas suatu 
produk. Pendidikan dan pembelajaran merupakan salah satu bentuk pelayanan pada masyarakat, sehingga harus memiliki kelayakan yang dapat memberikan rasa puas pada pihak yang mendapat layanan.

Pandemi Covid-19 yang terjadi di Indonesia bahkan dunia mengubah beberapa tatanan kehidupan, termasuk penyelenggaraan pendidikan pada tingkat satuan pendidikan. Mulai dari pendidikan tingkat dasar, menengah sampai pada perguruan tinggi. Status tanggap darurat bencana non alam Covid-19 di Kalimantan Tengah khusus nya dan dikeluarkannya Surat Edaran (SE) Kementerian Pendidikan dan Kebudayaan (Kemendikbud) Nomor 4 tahun 2020 seluruh sekolah pada tingkat satuan pendidikan langsung menerapkan sistem pembelajaran daring. Perkuliahan secara daring merupakan proses pembelajaran dengan mengintegrasikan koneksi internet bisa melalui aplikasi tertentu atau tidak atau dikenal juga dengan dengan istilah online learning (Bentley, Sellassie \& Shegunshi, 20I2). Perkuliahan secara daring saat ini dianggap cukup memberikan solusi, cukup praktis karena dosen dan mahasiswa tidak perlu hadir di ruang kelas, dapat dilakukan di tempat yang berjauhan, dan dapat dilakukan dari manapun berada. Menurut Fortune, Spielman \& Pangelinan (20II) beberapa masalah yang dihadapi dalam pembelajaran daring diantaranya materi ajar, interaksi belajar, dan lingkungan belajar. Robert \& Mclnnerney (2007) menegaskan bahwa beberapa masalah pembelajaran daring adalah kesesuaian materi ajar dengan kebutuhan mahasiswa, dan bervariasinya tingkat pemahaman mahasiswa tentang instruksi-instruksi dalam materi ajar. Tentu, pembelajaran daring tidak semaksimal dibanding dengan metode tatap muka, mulai dari persiapan orangtua menjadi guru di rumah, persiapan lainnya seperti adanya HP yang mendukung, biaya kouta, jaringan dan kemampuan anak dan orangtua memahami tugas yang di berikan. Lembaga Penjamin Mutu pendidikan (LPMP) Provinsi Kalimnatan Tengah telah melakukan survey terkait proses belajar mengajar sistem daring ditengah pandemi Covod-19. Hasil survey menunjukkan bahwa peserta didik memberikan respon positif dengan menyatakan pembelajaran daring menambah pengalaman baru mereka merasa senang. Pembelajaran daring juga mampu meningkatkan keterlibatan orangtua dalam proses pembelajaran, karena BDR (Belajar Dari Rumah) orang tua bisa mendampingi, membimbing, dan mengawasi tingkah laku anak-anaknya selama belajar di rumah. Orang tua bisa mendorong dan memberikan motivasi kepada anaknya secara langsung dalam proses belajar mengajar. Selain itu, melalui pembelajaran daring peserta didik bisa lebih mandiri, lebih komunikatif baik dengan orangtua, sesama teman dan guru, peserta didik juga semakin memahami bahwa fungsi ponsel tidak terbatas pada untuk games saja (KALTENG POS). Survey yang dilakukan LPMP Kalimantan Tengah sangat diperlukan untuk mengetahui persepsi responden yang terlibat dalam pembelajaran secara daring.

Persepsi mahasiswa tentang pembelajaran daring perlu digali sehingga menjadi pertimbangan bagi dosen yang menggunakan perkuliahan daring pada perkuliahan berikutnya. Persepsi merupakan apa yang dialami dengan segera oleh seseorang. Persepsi menghubungkan jalan kealam sekitar untuk mengetahui, mendengar, mencium, merasa, juga membau dengan segera berdasarkan alat indra. Menurut Slameto (2003) persepsi adalah suatu proses yang menyangkut masuknya pesan atau informasi ke dalam otak melalui indera manusia. Faktor yang mempengaruhi persepsi menurut Miftah Toha (2003) adalah I) faktor Intern terdiri dari perasaan, sikap, kepribadian, individual, prasangka, keinginan atau harapan, perhatian (fokus), proses belajar, keadaan fisik, gangguan kejiwaan, nilai dan kebutuhan juga minat dan motivasi diri individu 2) Faktor Ekstern terdiri dari latar belakang keluarga, informasii yang diperoleh, pengetahuan dan kebudayaan sekitar, intensitas, ukuran, keberlawanan, pengulangan gerakan, hal-hal baru dan familiar atau tidak ada saingan suatu objek.

Menurut Siahaan (2018) perkuliahan daring memiliki kelebihan dan kekurangan. Kelebihan pembelajaran daring yaitu I) Tersedianya fasilitas e-moderating dimana pendidik dan peserta didik dapat berkomunikasi secara mudah melalui fasilitas internet secara regular atau kapan saja kegiatan berkomunikasi itu dilakukan dengan tanpa dibatasi oleh jarak, tempat dan waktu 2) Pendidik dan 
peserta didik dapat menggunakan bahan ajar atau petunjuk belajar yang terstuktur dan terjadwal melalui internet, sehingga keduanya bisa saling menilai sampai berapa jauh bahan ajar yang dipelajari 3) Peserta didik dapat belajar atau me-review bahan pelajaran setiap saat dan di mana saja kalau diperlukan mengingat bahan ajar tersimpan di komputer 4) Bila peserta didik memerlukan tambahan informasi yang berkaitan dengan bahan yang dipelajarinya, ia dapat melakukan akses di internet secara lebih mudah. Sedangkan kelemahan pembelajaran daring adalah I) Mahasiswa yang tidak yang tidak mempunyai motivasi belajar yang tinggi cenderung gagal 2) Tidak semua tempat tersedia fasilitas internet 3) Kurangnya personil dalam hal penguasaan bahasa pemograman computer 4). Kecenderungan mengabaikan aspek akademik atau aspek social dan sebaliknya mendorong adanya aspek bisnis/komersial.

Beberapa penelitian telah dilakukan terkait dengan pembelajaran daring. Nuryansyah (2018) penelitian dengan judul persepsi mahasiswa dalam pembelajaran online disimpulkan bahwa dalam perkuliahan online mahasiwa mendapatkan kesulitan dalam berinteraksi baik sesama mahasiswa maupun kepada dosen. Hal tersebut dibuktikan dengan tingkat persentase tinggi yang menunjukkan ketidaksetujuan terhadap pernyataan yang mengatakan interaksi mahasiswa dalam perkuliahan online telah berjalan dengan baik. Penelitian Muhammad Hamidi (2020) yang menunjukkan bahwa persepsi mahasiswa tentang pembelajaran daring pada mata kuliah praktik bersifat positif, dengan rincian aspek belajar mengajar sebesar $66,4 \%$, aspek kapabilitas (kemampuan dosen) sebesar 74,6\%, dan aspek sarana dan prasarana sebesar $72,7 \%$.

\section{METODE PENELITIAN}

Penelitian ini menggunakan pendekatan kuantitatif dengan rancangan desain analisis deskriptif. Populasi dalam penelitian ini adalah seluruh mahasiswa Fakultas Keguruan dan Ilmu Pendidikan Universitas Muhammadiyah Palangkaraya yang mengikuti perkuliahan secara daring pada 4 kelompok mata kuliah (Metodologi Penelitian Pendidikan, Teknik Penulisan Karya Ilmiah, Problematika Pembelajaran, dan Belajar Pembelajaran) dengan jumlah 123 orang. Variabel penelitian terdiri dari satu variabel terikat (persepsi mahasiswa tentang perkuliahan daring), dan 3 variabel bebas (jenis mata kuliah, jenis program studi, dan jenis kelain). Instrumen yang digunakan dalam penelitian ini berupa angket daring dalam format google form dengan pertanyaan sebanyak 17 item yang sudah divalidasi. Hipotesis yang diuji terdiri dari tiga, yakni (I). Ada perbedaan persepsi mahasiswa tentang pembelajaran daring di tinjau dari asal Prodi mahasiswa (2). Ada perbedaan persepsi mahasiswa tentang pembelajaran daring di tinjau dari mata kuliah yang ditempuh, dan (3). Ada perbedaan persepsi mahasiswa tentang pembelajaran daring di tinjau dari jenis kelamin. Teknik analisis data digunakan adalah analisis variansi satu jalur dengan analisis statistic deskriptif.

\section{HASIL DAN PEMBAHASAN}

\section{Persepsi Mahasiswa Perkuliahan Daring}

Data yang diperoleh melalui pengisian kuesioner dan pengolahan secara matematis. Hasil analisis varian satu jalur dengan variabel terikat: persepsi tentang perkuliahan daring dan variabel bebas; Program Studi (PGSD, Pend. Ekonomi), Mata Kuliah (Metodologi Penelitian, TPKI, Belajar dan Pembelajaran, Problematika Pembelajaran SD), dan jenis kelamin (laki-laki, perempuan).

Hasil analisis data disajikan pada tabel sebagai berikut: 
Tabel I Perbedaan persepsi mahasiswa berdasarkan prodi :

ANOVA

Persepsi

\begin{tabular}{|l|l|l|l|l|l|}
\hline & Sum of Squares & Df & Mean Square & F & Sig. \\
\hline Between Groups & 36.864 & I & 36.864 & 2.421 & .122 \\
Within Groups & 1857.556 & 122 & 15.226 & & \\
Total & 1894.419 & 123 & & & \\
\hline
\end{tabular}

Dari tabel I di atas menunjukkan bahwa Sig $0.122>$ 0.05 dengan nilai $F=2,421$ sehingga Ho ditolak. Dengan demikian disimpulkan bahwa pada populasi mahasiswa FKIP UM Palangkaraya, tidak ada perbedaan persepsi tentang perkuliahan sistem daring jika ditinjau dari program studi mahasiswa. Tidak adanya perbedaan persepsi mahasiswa tentang perkuliahan sistem daring diduga karena faktor kebutuhan yang searah. Pandemi Covid-19 yang meliburkan proses perkuliahan menyebabkan pembelajaran daring menjadi suatu kebutuhan dan menjadi pilihan yang danggap paling tepat. Hal ini senada dengan pendapat Sarlito (2000) faktor yang mempengaruhi persepsi salah satunya adalah kebutuhan sesaat maupun yang menetap pada diri seseorang, kebutuhan yang sama akan menyebabkan persamaan persepsi begitu pula sebaliknya.

\section{Tabel 2 Perbedaan persepsi mahasiswa berdasarkan mata kuliah}

Persepsi

\begin{tabular}{|l|l|l|l|l|l|}
\hline & Sum of Squares & df & Mean Square & $F$ & Sig. \\
\hline Between Groups & 48.113 & 3 & 16.038 & 1.042 & .376 \\
Within Groups & 1846.307 & 120 & 15.386 & & \\
\hline Total & 1894.419 & 123 & & & \\
\hline
\end{tabular}

Dari tabel 2 di atas menunjukkan bahwa Sig $0.376>$ 0.05 dengan nilai $F=1,042$ sehingga Ho ditolak. Dengan demikian disimpulkan bahwa pada populasi mahasiswa FKIP UM Palangkaraya, tidak ada perbedaan persepsi tentang perkuliahan sistem daring jika ditinjau dari mata kuliah yang ditempuh oleh mahasiswa. Tidak adanya perbedaan persepsi mahasiswa tentang perkuliahan sistem daring diduga karena faktor eksternal mahasiswa yaitu ukuran dan penempatan dari objek atau stimulus. Meskipun berbeda mata kuliah yang di tempuh, namun antara responden memiliki hubungan yang sama, berasal dari mahasiswa keguruan (FKIP). Menurut Gibson, dkk (dalam Jenny, 20I2) faktor eksternal yang mempengaruhi persepsi seseorang diantaranya ukuran dan penempatan dan objek atau stimulus, faktor ini menyatakan bahwa semakin besarnya hubungan suatu objek, maka semakin mudah untuk dipahami. Bentuk ini akan mempengaruhi persepsi individu dan dengan melihat bentuk suatu objek individu akan mudah untuk perhatian pada giliran membentuk persepsi. 
Tabel 3 Perbedaan persepsi mahsiswa berdasarkan jenis kelamin

\section{ANOVA}

Persepsi

\begin{tabular}{|l|l|l|l|l|l|}
\hline & Sum of Squares & Df & Mean Square & F & Sig. \\
\hline $\begin{array}{l}\text { Between } \\
\text { Groups }\end{array}$ & 209.413 & $\mathrm{I}$ & 209.413 & 15.162 & .000 \\
Within Groups & 1685.006 & 122 & 13.812 & & \\
Total & 1894.419 & 123 & & & \\
\hline
\end{tabular}

Dari tabel 3 di atas menunjukkan bahwa Sig $0.000<0.05$ dengan nilai $F=15,162$ sehingga Ho tidak ditolak. Dengan demikian disimpulkan bahwa pada populasi mahasiswa FKIP UM Palangkaraya, ada perbedaan persepsi tentang perkuliahan sistem daring jika ditinjau dari jenis kelamin mahasiswa

Jika ditinjau dari data mean atau rata-rata sampelnya, maka perbedaan tersebut dapat dilihat dari tabel berikut :

Tabel 4 Data Mean atau rata-rata sampel

\section{Report}

Persepsi

\begin{tabular}{|l|l|l|l|}
\hline $\mathrm{Jk}$ & Mean & $\mathrm{N}$ & Std. Deviation \\
\hline $\mathrm{I} .00(\mathrm{~L})$ & $36.842 \mathrm{I}$ & 38 & 3.60575 \\
$2.00(\mathrm{P})$ & 34.0233 & 86 & 3.76353 \\
Total & $34.887 \mathrm{I}$ & $\mathrm{I} 24$ & $3.9245 \mathrm{I}$ \\
\hline
\end{tabular}

Dari tabel 4 di atas disimpulkan bahwa mahasiswa laki-laki cenderung lebih positif persepsinya tentang perkuliahan daring dibandingkan dengan mahasiswa perempuan. Perbedaan persepsi mahasiswa ditinjau dari jenis kelamin diduga dipengaruhi oleh faktor perhatian yaitu perbedaan fokus antar satu orang dengan orang lainnya, menyebabkan perbedaan persepsi antara mereka. Laki-laki cenderung memiliki kematangan emosi yang baik dibanding perempuan. Menurut Bischot 1996 dalam Komarudin (2016) seseorang yang memiliki kematangan emosi akan lebih mampu bersikap realistik, mudah menyesuaikan diri, mampu menyelesaikan persoalan secara objektif, tidak bergantung pada orang lain, mementingkan etika dan moral, mudah berempati, memiliki kreativitas serta senang tantangan. Hal ini juga senada dengan hasil penelitian Zahara (20/3) menunjukkan bahwa adanya perbedaan kematangan emosi pada remaja laki-laki dan perempuan dimana hasilnya remaja laki-laki memiliki tingkat kematangan emosi lebih tinggi dibandingkan remaja perempuan.

\section{Kesimpulan}

Berdasarkan hasil penelitian dan pembahasan, maka dapat disimpulkan bahwa pada populasi mahasiswa FKIP UM Palangkaraya, (I) tidak ada perbedaan persepsi tentang perkuliahan sistem daring jika ditinjau dari program studi mahasiswa, dengan nilai $F=2,42 \mathrm{I}$ dan Sig $0.122>0.05$, (2) tidak ada perbedaan persepsi tentang perkuliahan sistem daring jika ditinjau dari jenis mata kuliah yang ditempuh mahasiswa, dengan nilai $\mathrm{F}=1.042 \mathrm{dan} \mathrm{Sig}$ $0.376>0.05$ (3) ada perbedaan persepsi tentang 
perkuliahan sistem daring jika ditinjau dari jenis kelamin mahasiswa, dengan nilai $F=15.162$ dan Sig $0.000<0.05$.

\section{Rekomendasi}

Hasil penelitian ini dapat di rekomendasikan untuk beberapa pihak, yaitu:

I. Bagi pimpinan PT bidang akademik, sebaiknya disediakan fasilitas wifi yang lancar untuk bisa di manfaatkan mahasiswa, membuat SOP perkuliahan daring, sehingga bisa di pantau dan di evaluasi serta tidak merugikan mahasiswa.

2. Bagi Dosen Pengampu mata kuliah, agar bisa melakukan inovasi dan variasi dalam perkuliahan daring, tidak bertumpu pada satu model yang mennggunakan kouta lebih banyak.

3. Bagi mahasiswa dapat meningkatkan referensi bahan ajar dan meningkatkan kemandirian belajar.

\section{DAFTAR PUSTAKA}

Adijaya,N, Pudji Santoso,L. 2018. Persepsi Mahasiswa Dalam Pembelajaran Online. Wanastra Jurnal, I0(2), 550.

Dahar, Ratna Wilis. 20II. Teori-Teori Belajar Dan Pembelajaran. Jakarta. Erlangga.

Desmita. 2012. Psikologi Perkembangan. Bandung: Remaja Rosdakarya.
Hamidi, M, Maulana, H.A. 2020. Persepsi Mahasiswa Terhadap Pembelajaran Daring pada Mata Kuliah Praktik di Pendidikan Vokasi. Equilbrium_Jurnal Pendidikan. (10), 224-23I.

Hasanah,U. 2017. Persepsi Mahasiswa Terhadap Pelaksanaan Kegiatan Praktikum IPS Terpadu. Skripsi. UIN Syarif Hidayatullah, Jakarta.

KALTENG POS edisi Sabtu II Juli 2020. Palangkaraya. KALTENG POS press.

Sugiyono. 2011. Metode Penelitian Kuantitatif, Kualitatif Dan R\&D. Bandung: Alfabeta.

Suharsimi, A. 2013. Dasar-Dasar Evaluasi Pendidikan. Jakarta. Bumi Aksara

S. Siahaan. 2003. E- Learning (Pembelajaran elektronik) Sebagai salah Satu Alternatif Kegiatan Pembelajaran. Jurnal Pendidikan dan Kebudayaan, 9(42), 303-32I.

Tantri, N.R. 2018. Kehadiran Sosial dalam Pembelajaran Daring Berdasarkan Sudut Pandang Pembelajar Pendidikan Terbuka dan Jarak Jauh. Jurnal Pendidikan Terbuka dan Jarak Jauh, 19(I), 19-30.

Yusuf, A. Muri. 2014. Metode Penelitian: Kuantitatif, Kualitatif, dan Penelitian Gabungan. Jakarta: MediaGroup. 